\title{
Indonesian Pluralism and Democracy Under Challenge: A Social Reflection
}

\author{
Herdi Sahrasad \\ Graduate School of Paramadina University, Jakarta \\ Email:sahrasad@yahoo.com
}

\begin{abstract}
:
This article mainly concerned on the reflection of pluralism practice in the Indonesia context. Although, this issue is becoming a commitment for the government to implement it in the wider context of society, a number of challenges have been demonstrated in this research proving that pluralism is still a common problem in this country. The author illustrated a lot of cases in different areas which happened that threaten harmony and peace in the Indonesia life. This research discusses both pluralism and democracy as the two important entities which could not be separated. To some extent, most of the people here have not yet understood basically about significance and meaning of pluralism. So that the side effect of the misunderstanding, sociologically, sparks up social conflicts and issues of identity in the name of God, religion or other primordialism.
\end{abstract}

Keywords; pluralism, harmony, peace, democracy, primordialism

\section{Introduction}

In the recent years, violence against religious minorities often happens in Indonesia. The violence and intolerance against minorities in Tanjungbalai, North Sumatra in August 2016 , and Ahmadiyyah, Banten in February 2011, to mention a few examples, has become the collective memory for the religious minorities in Indonesia. 
Violence and intolerance in Tanjungbalai, North Sumatra occured when an angry Muslim mob burned down and damaged 12 Buddhist temples in Tanjung Balai, Saturday (30/07/2016). According to local authorities the mob was mobilized after an Indonesian woman of Chinese descent complained about the loud volume of the calls to prayer and Koranic recitals at the mosque that is situated in front of her house. One day later, seven people were detained by Indonesian police on suspicion of attacking the temples. ${ }^{1}$

In connection with similar event, several years ago the attack on Ahmadiyyah community in Cikeusik launched by a thousand residents of the village of Cikeusik to the congregation of the Ahmadiyyah in the village Umbulan, Cikeusik, Pandeglang, Banten, on Sunday, February 6, 2011. As a result of this attack, three people were killed, while two cars, one motorcycle, and one house destroyed and engulfed in mass batty, amok. ${ }^{2}$

Unfortunately, while the leaders of the country's largest Muslim organizations, Nahdlatul Ulama (NU) and Muhammadiyah, the two pillars of civil society, explicitly and unequivocally condemn the use of violence against Ahmadis, there has been a good deal of support for their forced disbanding. ${ }^{3}$

Actually, Islamic puritanism in Indonesia is getting more and more stronger .At least that what noted American anthropologist Clifford Geertz says in his book, After the Facts: Two Countries, Four Decades, One Anthropologist (1995), which concludes Geertz's four-decade research on Islamic Puritanism. Compared to the era of 1960s, this Islamic ideology in

\footnotetext{
${ }^{1}$ Religious Violence in Indonesia, http://www.indonesiainvestments.com/news/todays-headlines/religious-violence-indonesiabuddhist-temples-tanjung-balai-damaged/item7056

${ }^{2}$ Media Indonesia 05/2/2011 and Kompas 06-02-2011.

${ }^{3}$ Jacqueline Hicks, Heresy and Authority: Understanding the turnagainst Ahmadiyah

in Indonesia, KITLV, January $12, \quad 2013$
} 
Indonesia seems now to have become more visible in favor of the country's political gain. ${ }^{4}$

Such strong growth of Islamic Puritanism in Indonesia, as he furthered, is playing an important role of the spread of Islamic radical ideology.

In correspondence with Greetz's decade studies, Bahtiar Effendy of Muhammadiyah - the second largest Islamic organization in Indonesia - said that the influence of Islamic radicalization in Indonesia is becoming more visible owing to the country's political and economic instability, where the majority of Muslims still live in the poverty line.

Effendy believes that should the political and economy condition in Indonesia had been greatly improved, the influence of Islamic Puritanism or radicalism would have been dwindled.

In the eyes of Muslim puritans, on the other hand, Islam is the only way of life and therefore establishing khilafah (Islamic state) with the implementation of sharia (Islamic law) must be pursued regardless of the impact on the rights of other nonMuslim living in the state. To most Indonesians living in today's melting pot society, sharia is undoubtedly not what they want.

But the polling conducted by Indonesian Survey Institution (LSI) in October 2006 shows a concern that radicalism and Islamic fundamentalism are still prevalent in Indonesia, the world's largest Muslim population nation.

Based on 1,092 respondents from across Indonesia, with a 3 percent margin of error, "16.1 percent of respondents tolerate

4 Clifford Geertz, After the Facts: Two Countries, Four Decades, One Anthropologist,Cambridge: Harvard University Press, 1995. 
with the ideology of Jemaah Islamiyah, an organization accused of being the cell of al-Qaeda terrorist organization, and nine percent agree with the use of violent attacks like the 2002 Bali bombing as long as the attacks are aimed at defending Islam," LSI head Saiful Mujani remarked.

The survey showed 16.1 percent of the respondents support Indonesian Mujahidin Council (MMI), the country's hardcore Islamic organization, and are sympathetic to the organization's leader, Abu Bakar Ba'asyir who is also the alleged spiritual leader of Jemaah Islamiyah.

While 17.4 percent of the respondents tolerate with the ideology of Jemaah Islamiyah, an organization accused of being the cell of al-Qaeda terrorist organization. And 7.2 percent agree with the idea of Hizbur Tahrir Indonesia, hardliner Islamic group fervently campaigning for the establishment of sharia in Indonesia .

The latter is having an international gathering this August 12 as a means of getting support from international Muslim communities for the establishment of khilafah.

In general, the majority of Indonesian Muslims do not agree with the use of tactics in terms of jihad (holy war).

Speaking of the percentage, we can see that the number is low. In relation to the country's population, nevertheless, the figure is significant for a movement with a special agenda.

Having 10 percent of 200 million of Indonesian Muslims supporting the Islamic radical movement is potential to jeopardize the Indonesian sovereignty.

Here, we are talking about at least ten million can be the target of Islamic fundamentalist indoctrination. And with the country's tough transition, low economy and lack of education, 
any radical Islamic groups can easily recruit more followers despite a number of terrorist arrests in Indonesia .

\section{PLURALISM IS A PROBLEM?}

When we were in elementary school, our teachers and parents so often told us that Indonesia is multiethnic, multicultural and multireligious people. Under Pancasila (Five Principle), its state ideology, the Indonesian people can be live in harmony, and they are tolerant each other. For us, this story has been so nice dream at that time. ${ }^{5}$

But in 2007, during a two days workshop on Islam and Pluralism in Puncak. West Java, organized by Pusat Studi Islam \& Kenegaraan (Centre for Islam and State Studies) University of Paramadina, some young intellectuals of Muhammadiyah, Nahdlatul Ulama (NU) dan Paramadina recognized vehemently that pluralism is still under serious challenge in Indonesia. Many conservative ulamas have condemned pluralism and spread out their puritanism by using the Islamic institutions and mosques, included the institutions and mosques owned by the Muhammadiyah and NU for their dissemination of religious conservatism.

Zuhairi Mizrawi and Khamami Zada, the two young intelectuals of NU, Yudi Latif (University of Paramadina) and the three young intellectuals of Muhammadiyah namely Zakiuddin Baidhowy, Hilal Basya, and Ahmad Fuad Fanani (JIMMJaringan Intelektual Muda Muhammadiyah or Networking of Muhammadiyah Young Intellectual ) also worried that pluralism would be pushed aside by the conservative Islamic scholars and ulamas in Indonesia, included in Muhammadiyah and NU themselves. Muhammadiyah and

${ }_{5}$ Al Chaidar, Blake Respini and Herdi Sahrasad, From Shariaism to Terrorism, Islam in Indonesia Post-Authoritarian, forthcoming, Jakarta: Centre for Strategic Studies University of Indonesia (CSS-UI), 2015. 
NU, the two Islamic bastions for pluralism and tolerance, have been facing strong pressure from of puritant Islamists and fundamentalists who advocate "transnational Islam" for the ummah.

Why pluralism still a problem in this country, meanwhile since the birthday of this country in August 17-1945, it was coloured by a plural society?

To some extent, most of the people here have not yet understood basically about significance and meaning of pluralism. So that the side effect of the misunderstanding, sociologically, sparks up social conflicts and issues of identity in the name of God, religion or other primordialism.

As far as we observe, some Islamic organizations in Indonesia, such as Muhammadiyah, Al Irsyad dan Persatuan Islam (Persis) have not had favourable responses toward pluralism. Even, many Islamic analysts and scholars said, it seem that Muhammadiyah tend to be conservative in recently, compared with era of Ahmad Syafii Maarif leadership in the past. This point of view and perception is not without logical reasoning.

There are many facts and evidences that Muhammadiyah as a reformist Islamic organization during the last century has been shifting its paradigm orientation from critical position to be puritan one. Today, Muhammadiyah, actually, has not accepted and practiced pluralism in its real praxis. Meanwhile, the founding father of Muhammadiyah, $\mathrm{KH}$ Ahmad Dahlan, is a true pluralist, and he is very intensively dialogue with the priest, clergyman, Chinese, and scholars of other religions. Dahlan is an accomodationist, open-minded, inclusive and enlightment figure of Muhammadiyah at his time. Even Dahlan is never reluctant to take the other religious values as long as it will be useful and meaningful for the enrichment of ummah and for interest of universal humanity. Since the early years, Dahlan is a historic figure to reform Islam from within. However, nowadays Muhammadiyah has been changing. In its 
historical journey, recently Muhammadiyah has not been a modern Islamic organization that bring spirit of reform (tajdid). Muhammadiyah also has not have shares in solving of societal problems that is busier and dominant with the civil discourses such as liberalism, pluralism and secularism. On the contrary, Muhammadiyah tend to empower puritanism and to make it everlasting with rethoric and slogans back to Quran and Sunnah ( al-ruju' ila al-Qur'an wa al-Sunnah) without adequately critical attitude. So that, it is difficult to say Muhammadiyah now is modern religious and social movement as supposed by many peoples in general.

Be aware for this stagnation of thinking, most of the young intellectuals in Muhammadiyah, especially in the circle of Networking of Young Intellectuals Muhamamdiyah (JIMM) has resisted and revolted the establishment in the Muhammadiyah organization with arguing that the spirit of new reform should be implemented as raison d'etre to continue religious reform. JIMM has also revolted to the Association of Tarjih Decision (Himpunan Putusan Tarjih-HPT) because it has been considered as an "anti-critical holy book". JIMM has viewed HPT stipulation is out of Muhammadiyah school of thought. However, the young intellectuals' efforts to improve and empower Muhammadiyah reform has not get favourable response from the elites of the modernist-claiming Islamic organization.

In the last developments, the different view and perception between the old guards and the young intellectuals of Muhammadiyah not only happened ciclously in the war of discourse, but it has extended and escalated to internal violence with the dismissal of a promising, bright and young lecturer at Muhammadiyah University of Gresik (UMG) after the lecturer published an article in a regional newspaper (December 2006) explaining that the Ummah Islam are allowed to give congratulation of Mary Christmas for the Christian community. Muhammadiyah has also fired $M$ Dawam Rahardjo (a prominent Muslim intellectual) from the organization. In the meantime, Muhammadiyah support 
strongly the decision of MUI (Indonesia Ulamas Council) and Religious Affairs Department to forbid the Eden community and Ahmadiyah as well as their activities. This is a bad turn in religious-social politics in Muhammadiyah as a well-known modernist Muslim institution.

By this facts, many Muslim themselves are worry and anxious that Muhammadiyah would be a conservative movement and become new bastion of conservatism and puritanism. Regarding the emergence of the young intellectuals in JIMM, actually, Muhammadiyah has still a prospect for the future as a modernist Islamic movement that opened toward the changing related to pluralism, locally and globally. Muhammdiyah should be aware, in our opinion, that in the near future, the pivotal problem in Indonesia is how to manage pluralism by democratic means. The late John Bresnan (The Managing Indonesia,1993), formerly professor at Columbia University, has remind the state and society in Indonesia that managing pluralism coercively and repressively like as under the New Order is no longer relevant and proper to this country because its social and political landscape has been changed profoundly. ${ }^{6}$

Therefore, Muhammadiyah as a religious-civil society should continue its socio-religious reform in line with the time of reformation if the organization does not want to be keept away and neglected by the young Muslim intellectuals. Muhammadiyah should be aware that today, many Islamic organizations such as Majelis Mujahidin Indonesia (MMI), Front Pembela Islam (FPI), HTI (Hizbut Tahrir Indonesia) and other Salafy movements who has changed religious texts from otoritative to become otoritarian, borrowing Khaled M Abou El Fadl's perspective, has used and disseminated doctrines motivating and encouraging the Islamic radicalists and fundamentalists to speed up terrorism and other violent attacks.

${ }^{6}$ John Bresnan, Managing Indonesia, The Modern Political Economy. New York: Columbia University Press, 1993. 
If Muhammadiyah doesn't want to fall into particularism and puritanism, it must change the way of thinking from subjectively to objectively so that Muhammadiyah can do objectivication of religious thinking. Indeed, this objectivication- according to Kuntowijoyo, included externalization of religious thinking from Islamic faith to passing over other faith as a natural something. By this way of objectivication, Muhammadiyah would be tolerant, open minded, and pluralist Islamic organization that will be responsive the future challenge and problem. Accordingly, Muhammadiyah would be the bastion of religious civil-society for human rights, pluralism and democracy in Indonesia.

\section{PLURALISM AND MUSLIMS}

Pluralism, actually, is still under challenge in Indonesia. Why pluralism still a problem in this country, meanwhile since its birthday of this country, it was founded and coloured a plural society? To some extent, most of the people here have not yet understood basically about significance and meaning of pluralism. So that the side effect of the misunderstanding, sociologically, sparks up social conflicts and issues of identity in the name of God, religion or other primordialism.

As far as we observe, some Islamic organizations in Indonesia, such as Muhammadiyah, Al Irsyad dan Persatun Islam (Persis) has not have favourable responses toward pluralism. Even, many analysts and scholars said, it seem that Muhammadiyah tend to be conservative in recently, compared with era of Ahmad Syafii Maarif leadership in the past. This point of view and perception is not without logical reasoning.

There are many facts and evidences that Muhammadiyah as a reformist Islamic organization during the last century has been shifting its paradigm orientation from critical position to be 
puritan one. Today, Muhammadiyah, actually, has not accepted and practiced pluralism in its real praxis. Meanwhile, the founding father of Muhammadiyah, KH Ahmad Dahlan, is a true pluralist, and he is very intensively dialogue with the priest, clergyman, buddhist and scholars of other religions. Dahlan is an accomodationist, open-minded, inclusive and enlightment figure of Muhammadiyah at his time. Even Dahlan is never reluctant to take the other religious values as long as it will be useful and meaningful for the enrichment of ummah and for interest of universal humanity. Since the early years, Dahlan is a historic figure to reform Islam from within.

However, nowadays Muhammadiyah has been changing. In its historical journey, recently Muhammadiyah has not been a modern Islamic organization that bring spirit of reform (tajdid). Muhammadiyah also has not have shares in solving of societal problems that is busier and dominant with the civil discourses such as liberalism, pluralism and secularism. On the contrary, Muhammadiyah tend to empower puritanism and to make it everlasting with rethoric and slogans back to Quran and Sunnah ( al-ruju' ila al-Qur'an wa al-Sunnab) without adequately critical attitude. So that, it is difficult to say Muhammadiyah now is modern religious and social movement as supposed by many peoples in general.

Be aware for this stagnation of thinking, most of the young intellectuals in Muhammadiyah, especially in the circle of Networking of Young Intellectuals Muhamamdiyah (JIMM) has resisted and revolted the establishment in the Muhammadiyah organization with arguing that the spirit of new reform should be implemented as raison d'etre to continue religious reform.

JIMM has also revolted to the Association of Tarjih Decision (Himpunan Putusan Tarjih-HPT) because it has been considered as an "anti-critical holy book". JIMM has viewed HPT stipulation is out of Muhammadiyah school of thought. However, the young intellectuals' efforts to improve and empower Muhammadiyah reform has not get favourable 
response from the elites of the modernist-claiming Islamic organization. In the last developments, the different view and perception between the old guards and the young intellectuals of Muhammadiyah not only happened ciclously in the war of discourse, but it has extended and escalated to internal violence with the dismissal of a promising, bright and young lecturer at Muhammadiyah University of Gresik (UMG) after the lecturer published an article in a national newspaper (December 2006) explaining that the Ummah Islam are allowed to give congratulation of Mary Christmas for the Christian community. Muhammadiyah has also fired M Dawam Rahardjo (a prominent Muslim intellectual) from the organization. In the meantime, Muhammadiyah support strongly the decision of MUI (Indonesia Ulamas Council) and Religious Affairs Department to forbid the Eden community and Ahmadiyah as well as their activities. This is a bad turn in religious-social politics in Muhammadiyah as a well-known modernist Muslim institution.

By this facts, many Muslim themselves are worry and anxious that Muhammadiyah would be a conservative movement and become new bastion of conservatism and puritanism. Regarding the emergence of the young intellectuals in JIMM, actually, Muhammadiyah has still a prospect for the future as a modernist Islamic movement that opened toward the changing related to pluralism, locally and globally. Muhammdiyah should be aware, in our opinion, that in the near future, the pivotal problem in Indonesia is how to manage pluralism by democratic means. The late John Bresnan (The Managing Indonesia,1993), formerly professor at Columbia University, has remind the state and society in Indonesia that managing pluralism coercively and repressively like as under the New Order is no longer relevant and proper to this country because its social and political landscape has been changed profoundly. ${ }^{7}$ Therefore, Muhammadiyah as a religious-civil society should

7 John Bresnan, Managing. Indonesia: The Modern Political Economy, New York: Columbia University Press, 1993 
continue its socio-religious reform in line with the time of reformation if the organization does not want to be keept away and neglected by the young Muslim intellectuals.

Muhammadiyah should be aware that today, many Islamic organizations such as Majelis Mujahidin Indonesia (MMI), Front Pembela Islam (FPI), HTI (Hizbut Tahrir Indonesia) and other Salafy movements who has changed religious texts from otoritative to become otoritarian, borrowing Khaled M Abou El Fadl's perspective, has used and disseminated doctrines motivating and encouraging the Islamic radicalists and fundamentalists to speed up terrorism and other violent attacks.

If Muhammadiyah doesn't want to fall into particularism and puritanism, it must change the way of thinking from subjectively to objectively so that Muhammadiyah can do objectivication of religious thinking. Indeed, this objectivication- according to Kuntowijoyo, included externalization of religious thinking from Islamic faith to passing over other faith as a natural something. By this way of objectivication, Muhammadiyah would be tolerant, open minded, and pluralist Islamic organization that will be responsive the future challenge and problem. Accordingly, Muhammadiyah would be the bastion of religious civil-society for human rights, pluralism and democracy in Indonesia.

\section{Religion ideology and Khilafah (Islamic state)}

In relation to the above descriptions, in search of a solution to many complex problems of pluralism, and social imbalances in the archipelago, many Indonesians are in the peak of getting tired with the government's less effort towards combating poverty and social imbalance. Not to mention other issues like injustice, tyranny, corruption, lack of education and significant number of human rights violations. It is quite understood that 
the prolonged transition in Indonesia has not only given birth but also led to more loud voices of Islamic parties, calling for establishing Khilafah (Islamic state) as a way of building a better moral and prosperous nation.

Sounds like a promise, but for the pluralistic country like Indonesia this is not at all a good idea. Khilafah means combining Islam and politics in governance, and applying it in the archipelago having high diversities in religions, ethnics, cultures and economic disparity; Khilafah can be very dangerous.

Nonetheless, some Islamic parties and organizations have been inspired by transnational Middle East version of Islam. Prosperous Justice Party (PKS)—still remains as one of big political factions in the government - is a good example of an Islamic political party that follows the teaching of Ikbwanul Muslimin (Muslim brothergood) of Egypt .

Having motivated by the al-Qaeda, a notorious terrorist organization led by Osama bin Laden, Jemaah Islamiyah has been modeled by the style of al-Qaeda's Islamic Arabism. In addition, both Indonesian Mujahidin Council (MMI) and Hizbut Tahrir Indonesia also take that Islamic Arabism as their teaching direction. The Islamic Arabism also seems to have been the cloak of Islamic teaching in many pesantren (Islamic boarding), though not all, students at the pesantren are potential to breeding radicals.

And with Hizbut Tahrir Indonesia's having International Khilafah Conference in Jakarta this month, it is no more than an evidence that the teaching of religions in developing countries like Indonesia can be potential tool to reach a political gain by building practical relationship between individuals and groups. It is a transformation of religious political system, also known as religio-political system. 
This is also what Clifford Geertz claimed to be "religions mindedness," a process of how the religion ideology comes into existence.

In this context, the religion ideology has potential power to ignite fanaticism and radicalization that unquestionably can erupt violence and destruction. Any religion in this position will have two functions; building better integrity among its followers while creating conflict and violation.

The tragedy of Bali bombs, Australian Embassy bomb in Jakarta and other brutal acts done by anarchists like those from Jamaah Islamiyah, Islamic Defender Front (FPI) etc-where they use violence and destructive acts to close down businesses that they think is not in accordance of sharia like bar and café since they sell alcoholic beverages - are examples where fundamentalists have shown intolerant exclusiveness and belligerent sense of supremacy in facing minority communities.

While such brutality to some people is no less than a destruction by anarchists, many perceives that the stark terror attitude is a pure motivation by a number of Islamic extremist groups having their hidden agenda.

Facing this worrisome development in a pluralistic country, which the country itself indeed still struggle with many internal affairs, we really think that all Islamic groups should stop using violence in dealing with any contention or disagreement. They should not monopolize the truth of what they believe to indoctrinate others.

The debate khilafah is of a great relevance today, particularly with Hizbut Tahir had organized an international conference to be held on August 12,2007. The conference had definitely focused on building an Islamic state and thousands of members of the Islamic organization Hizb ut-Tahrir Indonesia (HTI) participated at that time. 
2007). However, whether an Islamic state is relevant to the Indonesia 's pluralistic communities should be taken in wise consensus. So far, presence of Hizb Tahrir Indonesia (HTI) becomes a problem and a challenge for the people of Indonesia.

\section{The Decline of State PoWER POST THE New Order ${ }^{8}$}

From the above explanations, the apparently rise in religious violence, primordialism, sectarianism and racial violence that threatens pluralism and democracy in Indonesia, can not be separated from the socio-economic conditions which is full of inequality and injustice.

Actually, Indonesia state and society beyond Soeharto's New Order is like a lame giant in Southeast Asia, in which its power is declining toward a failed state. In this situation of crisis, Indonesia needs a leader who has sense of crisis, sense of urgency and sense of direction and a genuine leader never thinks of himself/herself. Even, if needed, the leader must commit class-suicide and merged to be part of the oppressed to struggle together to overcome the multi crisis that has not abated the people until now. Here, the Islamic leaders who understand problems, has future visions and is rich in imagination to overcome problems, is considerably yearned for

8 Herdi Sahrasad, Indonesian State and Society post New Order, a paper for a limited discussion on Islam, State and Society in Indonesia Post Soeharto organized by activists of HMI (Islamic Student Association), PII (Pelajar Islam Indonesia), and Pimpinan Pusat GPII (Gerakan Pemuda Islam Indonesia) Menteng Raya Jakarta, in December 2004. 
by the people, who have been oppressed and hurt but cannot express their sorrow feelings.

In Indonesia, nowadays, the crisis of leadership occupies the central nervous system of all the multi dimensional crises in Indonesia. The crisis of leadership occupies the central nervous system when almost all initiatives of the public and existing social systems have been made impotent by the autocratic regime of the New Order in the past, the atmosphere of which still dominates even up to this transition period. The Muslim community such as Muhammadiyah, Nahdlatul Ulama, Partai Keadilan Sejahtera (PKS) communities and soon, can not avoid this bad reality, even they have been part of the ongoing problem. The radical Muslims even have been frustrated, disillusioned and radicalised.

The emergence of national figures, such as Nurcholish Madjid, Abdurrahman Wahid, Megawati Soekarnoputri, Wiranto, Amien Rais, Susilo Bambang Yudhoyono and Jusuf Kalla, is a transitional, political phenomenon, that is hoped by the ummah to be the problem solver and solidarity maker. But the history of post Soeharto era so often evidenced on the contrary.

In this context, the Muslim intellectual Nurcholish Madjid had stated the importance of having visionary leaders with revolutionary ideas, from among the the leaders, to solve the prolonged multi dimensional crisis of post Soeharto Order.

Concerning the 2004 presidential elections, the emergence of Yudhoyono-Kalla and then 2014 presidential elections with the rise of Jokow Widodo (Jokowi) is the new hope for the people by the elections, it is a logic consequence of the leadership crisis after the authoritarian Soeharto regime which has become the focus of psychological rivalry of politicians, private middle class, civilians, military and students, movements and NGOs. This is the breakdown of the New 
Order style of the former social political system that did not permit the reproduction of a new, fresh, creative and innovative leadership."

Currently, after the periode of Yusdhoyono and two years of Joko Widodo, we have seen that corruption, collusion and mismanagement in government and bureaucracy still embedded and escalated. Two years of Jokow Widodo administration is disappointed by the civil society, almost all public nerves are concentrated on the problem of seeking ideal leaders, as a solution to pull out the roots of national, regional and local leadership crises.

In this case, the Islamic people (the ummab) are one of sources of the national, regional and local leadership. However, the people can also become the source of mass anger, should the existing leaders fail to carry out their messages. For that reason, the national leaders must take care about people and become alert in order not to be stale. There are indications that our current leaders would become increasingly stale. In fact, the Islamic community admits, the Indonesian people are tired of seeking the national leaders who are able to help Indonesia solve the crises.

It is now more than 15 years of reform that was launched by student's movement since the downfall of Soeharto in the reform wave of May 1998. And three Presidents (BJ Habibie, Abdurrahman Wahid and Megawati Soekarnoputri) had handled the reform with achievements that disappointed the people. "Only God would know knows the duration of the leadership of the Gotong Royong Cabinet," said Hamzah Haz, the formerly Vice President once. That was an indication that the Mega-Hamzah duet was shadowed by fear and failures in implementing the message of reform from the students and people perspective. That is to say, if we want to be 
honest and gentlemen. Anyway, the Mega-Hamzah duet has not been able to give a light at the end of the dark tunnel. And how about Yudhoyono-Kalla? History tend to repeated itself.

History witnesses: Indonesia is continuously hit and rolled by the prolonging economic crises, also in the current era of transition of Habibie, Abdurrahman Wahid, Mega-Hamzah, Yudhoyono and Jokowi. Even the multi dimensional crises involving the social, political, legal and security sectors have increased and further deteriorated the situation. All of them stem from the crisis of credibility and morality as well as rationality. This situation creates anxiety and annoyance among the ummmah.

According to Muslim intellectuals perspective, if the Indonesian people want to quickly solve the crises and reembark on the nation and character building, the emergence of the national leaders, who are legitimate and credible with strong leadership, visionary insight and "genuine, authentic" nationalist spirit, not who are "hypocrites, pretenders, relativists or fake", becomes a must. The people are still waiting for the national leaders with such criteria and parameter, to solve problems and issues,

A long period of Soeharto era had elapsed when the recruitment of leaders had taken place in the horse trading market with the model of top elite dropping, when the money politics was as if "the god" who decided the fate of someone whether he becomes a winner or loser, when eventually the people got only " a cat in the bag", when leaders carried the name of the people, while as a matter of fact, it was only to serve the power interest of a political party, Leaders claimed 
that they knew the people, but the people never knew the leaders. ${ }^{9}$

\section{The Wise and Strong Leader Post the New Order}

All of us know that it is not an easy task to create or seek the ideal leaders and most of Indonesian people is still paternalistic, tradisionalistic and confused to the situation

It is mandating that we must have strong, visionary and legitimate leaders, as conditio sine qua non, because at present Indonesia is in the zone of danger or the red zone of a weak nation and character building that would lead to a failed state.

Indonesia will be saved and protected from becoming a failed nation, if it has strong leadership and visionary leadership as well as commitments to assist Indonesia in the areas of economy and social reconstruction, particularly in the efforts to uphold the law.

\footnotetext{
9"Our leaders in this period of transition are not as good as the generation of Soekarno-Hatta-Sjahrir, who had strong commitments, with also strong leadership weight and quality. The complexity of problems faced by the Habibie, Gus Dur and Mega-Hamzah genre could not be solved by themselves, because as leaders in the era of transition, they were not creative and did not have initiatives," interview with an Islamic intellectual Muslim Abdurrahman, and Hariman Siregar, former figure of Malari at the InDemo, Lautze, Jakarta, in mid June 2004.
} 
Robert I. Rotberg ${ }^{10}$ stated that Indonesia would face a hardship in several years in the future and needs a weighty and strong leadership to avoid a "failed state" and disintegration.

The serious problems faced by the Indonesian people at present are weak economy, Aceh and Papua separatist movements, as well as social conflicts. If the conflicts in Maluku and Poso are not immediately handled and disarmament is not conducted, the writer fears conflicts with ethnic, religion or language background will develop in other regions without clear causes. Here it is necessary to have government reinforcement based on law, decentralisation without disintegration and the strengthening of political values in a national way. Indonesia has the benefit of national strong sentiment, but has potential source to create political or economic instability. For that reason, it is necessary to have a strong and visionary leadership.

Although Rotberg admits that he does not study Indonesia in a special way, so that he cannot give an evaluation on the leadership of Megawati Soekarnoputri or mention someone who can save Indonesia from failure, $\mathrm{hi}^{11} \mathrm{~s}$ views are relevant to the present transitional situation.

10 Robert I. Rotberg the Director of Conflict Program of John F Kennedy School of Government, Harvard University, in a seminar conducted by the Centre for Strategic and International Studies (CSIS) in Jakarta (Kompas, March 28, 2002). See, Robert I. Rotberg, editor, When States Fail: Causes and Consequences, Princeton University Press, 2003.

11 "It is still necessary to keep maintaining the freedom of press, because it is a very important factor to prevent a country from undergoing failures," said Rotberg who also holds a post in the World Peace Foundation. 
There are four categories of nation building, namely strong, weak, failure and downfall. The phenomenon of country failure is not a new thing in the world. After the downfall of Russia, of 192 countries who were in the transition of democracy many were weak and facing dangers of failures, failed and many of them did fail in 1990 and several of them had fallen. Since that period considerable conflicts took place in countries killing at least nine million people and four million people become refugees in their own countries.

This became a threat for the world order. Under present circumstances, the world can no longer take the distance from the togetherness of weak countries or failed countries. The failure of a country does not only affect the security situation and peace of the relevant country, but also the neighbouring countries and the world order as a whole. For that reason, it is imperative for international organisations to prevent a country from becoming weak and failing. The weakness or failure of a nation-state originate in physical and geographical factors, historical factor resulting from the errors in the colonial period or foreign policies or other errors. However, the major factor of failure of a country is further caused by human factor. The wrong and damaging decisions of leaders considerably contribute to failures of a country. Borrowing the discourse of Rotberg, the indicators of a strong country are among others high levels of security and freedom, environmental protection for becoming economic growth, prosperous and peaceful, all of them are made possible by a strong leadership and supported by the people.

On the other hand, failed countries tend to face prolonged conflicts, not safe, communal violence, and the state violence is very high, hostility due to religion, ethnic and language, terrors, roads or other physical infrastructures are left decaying. Among the failed countries, namely Yugoslavia, Sierra 
Leone, Sudan, and Afghanistan. Those countries do not have authorities within the boundaries of countries and the authority of the country moves to the hands of war commanders in chief. As if the people lived without government, without security, without physical infrastructures for the people. There are about 42 countries in the world at present that are in weak condition leading to failures or downfall, among others, in the former territories of Soviet, Balkan, Africa, Latin America and Asia.

\section{Threat against Democracy Post the New Order?}

Recently, the Indonesian people, especially the Muslim community, who are now undergoing the process of democracy transition, are really about the situation of " multidimensional crisis", because now they were exactly on the crossroad of safety or road of destruction. If Indonesian society cannot pass this process of transition well, ${ }^{12}$ the threat we face is not only the process of disintegration of people (separation of a certain region from the territory of the Republic of Indonesia), but it is more fearful that there are the possibilities of social disintegration process or the destruction of social bond in the society. If the social bond is destroyed, social distrust will be created (a climate of mutual distrust) among social groups, so that one group in the public will be jealous of another group, hostile to each other or even kill each other. In this situation, mass brawls under the Thomas Hobbes style, war of all against all, is no longer only in the imagination.

12 Imam B. Prasodjo,"the End of Indonesia?" dalam Indonesia 2001, Kehilangan Pamor, penerbit Kompas, 2002. Imam is a lecturer of the Faculty of Social and Political Sciences, UI. 
Let's the writer to remind you that in Indonesia under President Megawati 2002-2004 and Yudhoyono 2004-2014, horizontal conflicts and power rivalry among political elite, both in the legislative and Executive institutions have dragged the people and country life to turmoil, tensions, and prolonged crises. In the past, the duet of Abdurrahman Wahid-Megawati Soekarnoputri, the duet of Megawati-Hamzah Haz and Yudhoyono who are expected to be able to solve problems, tend to turns out to bring the national decline, not only political decline but also social economic decline. The political assets is destroyed into splinters due to interest conflicts of the elite, who give the impression that they do not know themselves and are irrational, the economic capital melts due to the irregularities and the incapability of decision makers, members of the cabinet and national leadership to manage the economy, while the social capital is totally eroded due to the crisis of credibility of the public vis-a-vis national leaders.

Meanwhile, James Van Zorge in the past noted that under President Megawati, Hamzah Haz has taken an insubordination step towards President by visiting Laskar Jihad Jafar Umar Thalib in the detention room, Jakarta as a political indication of Islamic ideology and sectarianism ${ }^{13}$

Indonesia, which is currently being hit by multi crises, needs national leaders, who are voluntary and committed to sacrifice in the spirit of Jihad (under Islamic conviction) or martyrdom (under Christian faith), to arouse the spirit, activism and intellectualism along with all people's resources to save total reform which, in truth, is to save the people and the country.

13 Van Zorge Report, May 20, 2002 
In the past, leaders of the old generation, namely Abdurrahman Wahid, Megawati, Amien Rais, Akbar Tanjung, Hamzah Haz, Yudhoyono-Kalla, Yudhoyono-Buediono and Joko Widodo-Jusuf Kalla turn out to have ignored the historical opportunity to implement the reform visions which have been staked by millions of people, students and young generations with blood and tears. This old generation turns out to have been weak, full of intrigues, mutually fought each other and full of conflict of interest resulting in the seizure of power and money by empowering "Constitutionalism" as a legalformal weapon to maintain or topple power.

In fact, power and money are very strikingly demonstrated to the people in the form of luxurious official cars, which are far from the reality of people's life who undergo economic deprivation, marginal-ization and regimentation resulting from the disintegration and conflicts among the elite. The conflicts of the elite are tiresome and use up all resources, which should have been used by the grass-root people.

Students even accuse intellectuals and politicians, who engage in conflicts and power scramble, of having conducted moral and political betrayal. Wahid-Megawati-Hamzah, Amien and Akbar are the elites, who purposely drag horizontal conflicts deeper by relying on their charisma and their influence on the grass-root people who socially and culturally are being politic-ized and ideology-ized, which are not productive and creative, due to the low level of education, absence of employment opportunity or poor social life.

\section{Problem Solving and Solidarity Building Post the New Order}


The leadership style of the Soeharto New Order, which was centralistic, closed and authoritarian, had placed the society in a social deadlock. This social freezing finally collided with economic development, which rapidly changed the material basis of the society and collided with the liberalization that changed the mindset, state of mind and mentality of the public. The social change had moved very rapidly.

The crisis of leadership occupied the central nervous system of the multi dimensional crises in the economic, social, cultural and certainly political areas. The old system of leadership reproduction could not create public sphere for society to create quality leader. Will leaders emerge again of the calibre of Soekarno, Hatta, Sjahrir and the other Founding Fathers?

So far, Yudhoyono-Budiono, Amien Rais, Megawati, Gus Dur and Jokowi- Kalla are facing global economic uncertainty. In public sphere, there have emerged crowd leaders from seminar rooms, on newspapers, magazines and television programs, which do not have anything to do with the grass-root people. The irony is that the critical among the people is regarded as a threat against the existence of leaders of this model. These "teledemocracy and media-cracy" leaders have persuaded the people after the downfall of Soeharto with reformation slogans, empty of meanings. For that reason, the reforms in the eras of Habibie, Abdurrahman Wahid, Megawati,Yudhoyono are now tend to be ended. Obviously, the ummah (Muslims) cannot let this situation to go on. The ummah *Muslims) do not want failures after failures to beset the people, who have already collapsed.

The question, perhaps, is why after the Soeharto New Order it has been very difficult for us to find leaders who had the calibre of statesmen? We can find the answer in a simple way in the strong personalization of power and personification of politics 
in the transition era, which is the extension of shadow of the New Order, in which Soeharto as Father of Nation is still dominating. In the era of Soeharto regime, anyone who opposed him was regarded to have opposed to the ideology of Pancasila and law. "So, said Yap Thiam Hien, who is against Bapak (Father) is against the law and Pancasila, the sole ideology". In relation to the system and recruitment of leaders, Soeharto made the final decision. Even in deciding himself to be President, "Soeharto was elected by persons whom Soeharto had to elect Soeharto". Such things may not reoccur in the reform today.

The Soeharto era as a period had elapsed. But, mentally, the style of the former number one strong man has kept surviving in the arena of succession, although in variable dimensions. The domination of political parties in determining the legislative members, for instance, caused the party representative who claimed to be the people's representative was totally unknown to the people. Indeed, this effect is the risk of the option of a general election system so far, which is the proportional system. Like the presidential election system using the system of "partycracy", in which the party elite make the decisions, as they practise "horse trade" for, of course, the interest of the party. A party oligarchy that has proven to be unshakeable yet.

Whatever the rationalization, the leadership reproduction system of this political party oligarchy model denies the very rapid flow of social development, in which at present a new middle class and educated class have grown in a large scale. Also in this era of transition, there has emerged a layer of sophisticated Indonesian society, which is cleverer and critical, both due to education and free flow of information, and as a consequence of their intense active relationship with the big current of globalisation have become the motor of democratisation. 
For this kind of society has elapsed the very long period when the recruitment of leaders took place in the horse trade market in an upper-elite dropping model, when money politics acted as if it were the "God" who decides "the fate" of someone whether he will be a winner or a loser, when the people finally shared merely "a cat in the bag", when leaders spoke about democracy; while in fact it's a Party-cracy., when the authorities of parliament and executives admitted knowing the people while the people did not know them, claiming to be pro dialogs and anti violence, but tended to monologue as well as fond of provoking very unruly radicals.

When the time comes for leaders to undergo the public selection process from the bottom, called by inner conscience and not material gain, to bring the people out of the prolonged crises. This nation opens the widest "vacancy" for strong candidate leaders, visionary and legitimate, because at present Indonesia is in the red danger zone, as a nation state Almost all requirements have been met to move into a nation-statehood that totally fails and break into splinters.

We need alternative leaders, who have a tradition in discursive handling of conflicts, habits of solving problems through sharing, bargaining and win-win solution. In addition, the strengthening of compliance with the rules of the game, the willingness to simply accept a win-defeat situation as well as honesty to take on public accountability. Certainly, as the main basis, it is necessary to be engulfing the power analysis and the power of responsiveness, oriented to problem solving, not to complicate problem, as well as clarity of ideas and adaptive capability toward ever-changing development. 
Although this nation has been hit right-left, front and back, and up and down in a very dark cave, this nation has not seen a light at the end of the tunnel. One by one candle of hope withers, although they have not been completely snuffed. The change from one President to another, for instance, has only created a remnant of hope, not a substantial change. Every time the moment of succession comes, the hope develops and the irony is that it always ends up with totally empty wrapping.

The Indonesian leaders in the era of transition are not as good as the generation of Soekarno-Hatta-Sjahrir-Natsir, who proved to have strong commitment and quality of leadership. The multi crises in various walks of life due to the Soeharto leadership style had further deteriorated under the genre of Habibie, Gus Dur, especially Megawati, Yudhoyno and Jokowi who had poor creative and innovative ideas.

Meanwhile, millions of refugees and thousands of others are killed or made invalids in horizontal conflicts in Ambon, Maluku, Aceh, Irian Jaya, Sampit, Poso, Mataram, West Kalimantan, Cikeusik, Tolikara Papua, Tanjungbalai North sumatera and other regions, indicating that the present state and government do not have the capacity to overcome multi crisis in Indonesia and are threatened with disintegration.

The conflicts of interest among the national elites, which spread to lower class, become horizontal conflicts, have caused the people to lose the country and on the other hand, they have caused the country to lose its people. There is a discontinuation, outward and inward, between the country and its people, who are continuously oppressed by the prolonged economic, social and political crises. 
The above mentioned bitter and painful facts remind someone of the views of Toynbee and Duane Elgin regarding the public which reaches the level of downfall, in which, according to both western scientists, is a public the function and role of the institutions of which are not understood any more and increasingly uncontrollable. The social consensus and common objective vanish. Political and social relations are in chaos. With the downfall of social consensus, various social interests compete each other to gain domination. The bureaucracy, who govern the people who are degrading cannot handle the problems any longer, which have become increasingly complicated, with loss of legitimacy, and the absence of common objective, the creativity, vitality and the strong determination of the apparatus, vanish quickly in the downfall spiral into the confusion and chaos of bureaucracy.

The situation can no longer be acceptable and maintained. The need for fundamental change is urgent. Here, the ummah under the Yudhoyono-Kalla government has been challenged seriously to bring the profound change. Change for better, for social justice and social democracy.

\section{$* * * *$}

\section{Toward a Consolidated Democracy?}

In Indonesia post the New Order, the emergence of Yudhoyono in 2004-2014 and the Jokowi in 2014-current, for instance, as the democratic leaders are supported by the ummah, the muslim society with high expectation for a better new Indonesia. Their success or failure would be a political lesson by the ummah in the next presidential elections.

Universally, ${ }^{14}$ the measure of success of a transparency toward democracy is stated to be the establishment of a

14 Susilo Bambang Yudhoyono, Konsolidasi Demokrasi, paper, Menko Polsoskam, 2002 
consolidated democracy that has the characteristics of stable attitude, behavior and constitutionalism.

According to Juan Linz and Alfred Stepan, in "Problem of Democratic Transition and Consolidation" it is stated there are five arena of consolidated democracy, namely a civil society marked by the freedom of communication and assembly; political society marked by general, free, and inclusive general election, rule of law, which highly respects constitutionalism, state apparatus in which the norms of a legal-rational bureaucracy are alive, and economy society that is characterized by the establishment of a healthy market institution. ${ }^{15}$

Observing the character and description of such a consolidated democracy, we would agree that it is life in such a society that we want to develop in our country in the coming century. ${ }^{16}$ Indeed, the challenge is big. But, if we realize how costly the price that must be paid by the Indonesian people due to our negligence to establish a genuine life of democracy in the past, although our stability and economy properly grew, we now must position the task of establishing a consolidated democracy as the main national agenda in the future.

We are probably interested in how criteria for success as a nation developed by Wicker - Miurin ${ }^{17}$ and their team. By observing and evaluating the progress of the European

15 Juan Linz and Alfred Stepan, Problems of Democratic Transition and Consolidation, Baltimore: The Johns Hopkins University Press, 1996

16 Susilo Bambang Yudhoyono, ibid

${ }^{17}$ Newsweek special edition of December 1999 - February 2000 
countries and their readiness to face the future, a ranking is made for each country in the region. Of course we would want to include our country in the ranking system of progress and readiness of a nation using such a model. But what we should observe are the idea and approach in measuring the criteria for success.

There are four (4) measures established, namely sustainability, fairness and individual freedom and harmony and readiness for the future. The sustainability of a nation is measured from the economic growth, environmental maintenance and public health. The fairness and individual freedom are reflected in employment in the education work, life expectancy rate and income and the like, which basically indicate that each citizen has an equal opportunity to grow and develop the measure of success on fairness and individual freedom very important for us to be concerned about jointly, because the gap in this country is very big, both social gap, economic gap, and intellectual gap. It is necessary to evaluate the public harmony because a peaceful, harmonious and orderly society is the longing of every human being. Such a society has the capacity to resolve conflicts, such as riot, crime and especially anarchic actions. Recognizing the very plural condition of the Indonesian society, full of sources of conflicts and seeing our experience, especially of the past several years, we must be successful in institutionalizing the management of conflicts in the future. Not by using the repressive and top down model and approach, but an institutionalized mechanism, in which the society has the awareness and facility to solve social problems ${ }^{18}$.

Certainly, this big effort must be accompanied by an increasingly stable culture and law enforcement. The enforcement of law in fair, consistent and sincere ways will be able to prevent chronic social disorders. The fourth criterion, if

18 Susilo Bambang Yudhoyono, Konsolidasi Demokrasi, paper, Menko Polsoskam, 2002 
we borrow the model developed by the Wicker - Miurin team, is readiness for the future. The emphasis on this fourth criterion is the mastery of technology. Therefore, the ownership and control of telecommunication, the Internet, research and development and other similar institutions are absolutely needed by a modern country. In the spirit of critical reflection at the end of this century and while we are readying to enter the new century, the criteria of readiness and success I have earlier explained should be used to measure our life, our own selves.

Where is the Indonesian people standing at present? What tasks and work should we together do in the next year and future decades? In short, Yudhoyono said during his presidential campaign, he sincerely wants to develop a better New Indonesia. ${ }^{19}$

\section{Anomaly and Abnormality of Our Democracy Post The New Order}

How to answer the above questions, and how to make a better Indonesia, prior to the presidential elections in 2014, there are people questions: Can the legislative elections in 2014 lead to lawmakers with better quality compared with the 2009 election? From some discussions in different cities and regions, the writer gets that the answer is skeptical, even pessimistic. Instead of producing a quality member of parliament, it is almost certainly the politicians resulted in the parliamentary election of 2014 will be more pragmatic and prone to corruption. Why is that?

Today political corruption is rampant and it is inseparable from the high political cost. Politics is increasingly transactional and leads our society to the brink of criminal democracy. It

19 Susilo Bambang Yudhoyono-Jusuf Kalla Visi dan Misi Kandidat Presiden, The Brighton Institute: materi-pamlet kampanye pemilihan presiden, 2004. 
should be highlighted that the political fund is very expensive and the investment should be returned when a person occupies a public office in the parliament or the executive. Imagine, for a prospective member of the House of Representatives, a candidate must spend a minimum of Rp1 billion, a figure that in the eyes of the common people, is very large. As for the presidential elections, according to former Vice President M. Jusuf Kalla, now it needed funds worth millions of US dollars.

Indonesian Corruption Watch (ICW, 2009) reveals that the regular salary and benefits of parliamentary member received, is not sufficient to restore the investment so that corruption is the only option or way to raise capital as well as investment returns to defend the next period title.

Even, winning the election becomes more expensive when the political parties and legislative candidates and the organization do not have a network that reaches down to the grass roots. The absence of political infrastructure is then compensated by the politician to purchase the advertising in the mass media, charitable acts, money politics and hiring professionals staff for self-imaging, in which the cost becomes more and more expensive.

In this regard, the lack of political infrastructure also leads to political parties and candidates could not garner donations from members or supporters that rely on big donors, especially businessmen or well-to-do financiers (capitalists). This leads to political parties and politicians becoming less self-sufficient, and prone to corruption as a political price to be paid in groups or alone.

In this case, businessmen or well-to-do financiers (capitalists) are a major contributor to this, and then they will ask for compensation from the government projects that encourage political corruption. While, the lack of political infrastructure also pose problems of political representation. 
The analysts then saw, a situation is increasingly crisis because politicians who have no ties with constituents tend to blinddeaf to the voice of the public and continue to spend the budget for traveling abroad or build another wasteful project despite a widespread public rejection and distrust.

If we check out, the majority of the politicians involved in corruption tends to work to protect themselves from the law. They want to get power not because they want to serve the people, but to look for money, privillege and enjoyment of power.

This conditions would undermine the political system which we aspire. If political parties as a upstream of political system is dirty and not trustworthy, then the product will not be clean, such as the legislative and executive authorities, policies, supervision, budgets, and legislation. The process will only take us to criminal democracy at the expense of the interests of the people. Political parties only think the short term and narrow, for example piling purse and coffers after winning the 2014 election, while the programs for the people surely forgotten.

In such situations, the ideal function of political parties will fail, unfulfilled. As a result, political parties would be difficult and tough to fight for public aspirations. It is too hard to establish substansial democracy, develope political ethics, or makes laws in favor of the people. The next result, public confidence in the political parties, democracy, and politics increasingly fallen sharply.

And now there are the growing symptoms that corrupt politicians in general do corruption to recover and restore the economic capital that they used in politics. This is related to the high costs that must be borne in criminal democracy today. 
As a result, transactional democracy, even criminal democracy increasingly inevitable.

What I have described above is parallel with the perspective of Larry Diamond (2004) who described the situation "move in the other direction that is not clear" in many new democracies in Asia (including Indonesia) and Latin America, which ultimately resulted in the insecurity and corruption. Actually, it is more difficult and complex situation because of the failure of civil society to maintain, consolidate, giving vitality and meaning to democracy itself. Larry Diamond can not deny that the transition towards what he describes as a move towards "something else" with symptoms of anomalies and abnormalities. ${ }^{20}$

Say, "the abnormality of transition", which is characterized by weak governance, plutocratic regime, oligarchism, corruption, violence, identity conflict, and money politic that damage to law enforcement, and political instability.

Various cases of corruption by politicians in parliament (Hambalang, Centurygate, imported beef, Wisma Athletes, and so on), sectarian violence against the Ahmadiyah and Shia, the difficulty of building a church / house of worship and so on, are a reflection of the " tip of the iceberg" from the depth current of transactional democracy, even criminal democracy in Indonesia, a symptom of anomalies and abnormalities that worries us.

A new Indonesia that stemmed from national commitment and ideals, from the message of the constitution, and people's awareness and aspirations, which keep developing from one period to the next, is very significant.

Did Joko Widodo (after the Yudhoyono failure) keep his commitment and promise to the ummah, the Indonesian

${ }^{20}$ Larry Diamond and Leonardo Morlino, The Quality of Democracy: An Overview", Journal of Democracy 15 (October 2004), pp. 20-31 
people to build a better new Indonesia ? The history has witnessed that under Jokowi, corruption is very rampant and violence toward religious minorities, such as in Tanjungbalai, was occurred, whilst marginalization of the peasant and underdog such as in Bima (NTB), Kalimantan and MesujiLampung, are very hard. Jokowi regime, such as Yudhoyono Regime, is potentially failed or very weak, so that the people disappointed, even part of them frustrated vehemently, and as if Indonesia is going to nowhere under President Jokowi.

Really, Indonesian state and society under liberal democracy are still facing uncertainty in the near future because the weakness of law enforcement and legal certainty, also the weakness of the national leadership under the tyranny of capital and oligarchs. Jokowi government must work extra hard and smart to deal with global uncertainty, and in fact, if it is necessary, Jokowi cabinet must work 24 hours/day. 